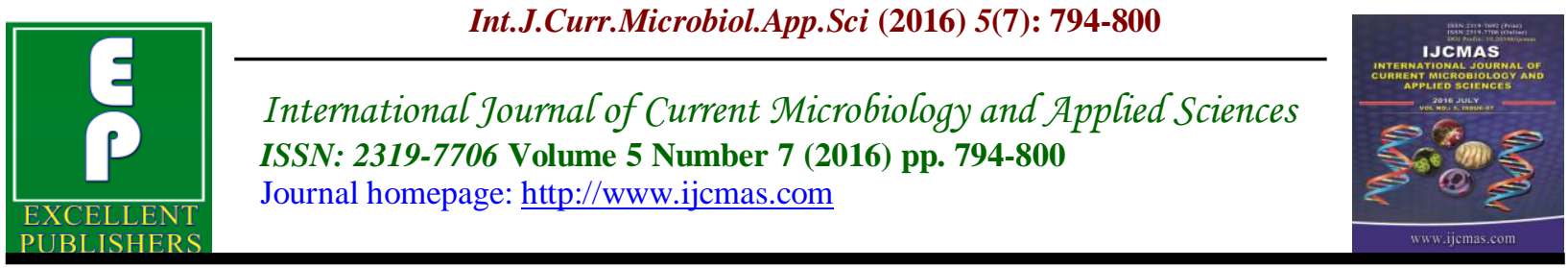

Original Research Article

http://dx.doi.org/10.20546/ijcmas.2016.507.091

\title{
Self-Protecting from Drugs for Hills Tribe Youth Living in Border Area of Northern Thailand
}

\author{
Narongsak Noosorn* and Chakgarpan Phetphoom \\ Faculty of Public Health, Naresuan University, Phitsanulok, Thailand \\ *Corresponding author
}

\section{A B S T R A C T}

\section{Keywords}

Hills Tribe Youth,

Self-Protecting

from Drugs,

Northern

Thailand.

\section{Article Info}

Accepted:

25 June 2016

Available Online:

10 July 2016
This study investigates Self protecting to reduce risk of the drugs relative of hillsman youths Amphoe PhobPhra, Tak Province. and study factors which effect to mind protecting to reduce risk of the drugs relative of hillsman youths Population in this study are children and youths who are in education or uneducated. There are covered male and female living at hills Amphoe PhobPhra, Tak Province, age 10 to 17 years old, for 596 persons. There were sample distribution following population for 223 persons. Research Tools consists of opened and closed Questionnaire which we could get personal information from sample. In the questionnaire, there are question follows 1) Basis inquiries, 2) General inquiries, 3) Health inquiries, 4) Social inquires, 5) Cultural inquiries, 6) Drugs inquiries and 7) Mind protect from drugs inquiries. Data was computed by Statistics, Mean, Standard Deviation; S.D. and predicted factor using Binary Logistic Regression and Odds ratio including95\% Confident Interval; CL. The result found that self-protecting behavior from drugs was showed that 134 persons or $57.5 \%$ obey teaches or elder about drugs irrelevant, 133 persons or $57.1 \%$ for parents warning about drugs relating or drugs using and there are 129 persons or $55.4 \%$ who don't use drugs because of family disgrace respectively. Value of self-protecting from drugs behavior could be predicted by equation as $59.80 \%\left(\chi^{2}=6.455, * \operatorname{Sig}=.05, \mathrm{R}^{2}=\right.$ $.598)$. There are factors which have relative to self-protecting from drugs behavior as being with friends, deprivation and go night out. It could be predicted self-protecting from drugs behavior statistically significantly 0.05 (Wald $=4.955$ and6.733).

\section{Introduction}

People who use the drugs was induced to have negative behavior such as crime, prostitution or being unemployed that always happen because of drugs (Office of Narcotics Control Board, 1983). Over the last 20 years, research has demonstrated that the prevalence rates for childhood trauma are alarmingly high, and that adverse experiences have enduring impacts that lead to a number of negative health and behavioral outcomes. The United Nations, UN, estimated that in 2002, there were 149 to 272 million peoples who are 15 to 64 years old, have been used drugs that increase from 90's century for 15 to 39 million persons. Cannabis is popularly used for 125 to 203 million peoples and others used 
Amphetamine-type Stimulant drugs (ATS) such as Methamphetamine, Amphetamine, and extacy opiates derivative and cocaine (International Cooperation suppression Bureau Drug, Online).From the drugs production at Thailand frontier, manufacturer and supplier who were arrested, let minorities take the drugs to country especially hills man who they have relation as cousins with Thai and neighboring countries more than 300 thousands peoples on the current (Office of Narcotics Control Board, Online).

The drugs at Thailand frontier which is long time problem has affected our country as Drugs and Drugs Supply Defensive Measure. There are drug trade smuggling at frontier for long time. This is major problem in Thailand where is passageway and destination country especially the Northern of Thailand (Thana Yottrakul, 2008).For this frontier, there were 150 to 200 thousands pills per month which is $1 \%$ from all of imported drugs from frontier. They take the drugs from the upper Northern and the Northeastern through the lower Northern to inner area and take from the upper Northern to customer at lower Northern directly. They operate by minorities supply network. Especially, they take the drugs shelter at village area where is opposite frontier or parallel village with other shelter, waiting for sending to customer or other supplier. (Office of Narcotics Control Board, Online).

Many Government department have more anti-drugs campaign that the problem could be relieve some extent. However the drugs is long time problem. The drugs suppressing is not only one way to solve all problem. People especially youth should be learn, known and realize how dangerous of drugs. Including they should be implant and have anti-drugs social values that is another way to prevent the drugs problem. (Food and Drug Administration, Online).
Over the last 20 years, research has demonstrated that the prevalence ratesfor childhood trauma are alarmingly high, and that adverse experienceshave enduring impacts that lead to a number of negative health. (Jill Levenson \& Melissa Grady, 2016) The youth who will be new generation in the future was more related with drugs that become the highly effect to life, social wealth and national stability also. The mostly problem that involved them in the drugs are drinking alcohol, having night out, gambling, spending money wastefully, family problem(broken family), surrounding (near drugs supply area), economy (being unemployed) and by themselves (want to know and try). These problems will be grow up until they finally use drugs (Pranee Sutthisukhon and others, 2008). As we follow situation of children and youths living in the hill where is risk area, Amphoe Phob Phra, Tak province, children and youths use drugs such as alcohol, cigarette, amphetamine, volatile and cannabis. Furthermore they also use cough mixture and Antidepressant (From village community survey on 2012, Amphoe PhobPhra). For all of these, we would like to study Mind Protecting from Drugs for Hillsmen Youth Living Frontier at Amphoe PhobPhra, Tak Province, to study Mind Protecting to reduce risk of the drugs related of hills man youths. This discovery is going to fulfill invention machines, solving the problem and improve mind protecting of children and youth in this area and reduce drugs using permanently.

The main objectives of this study to self protecting and to reduce risk of the drugs relative of hills tribe youths in border area of Northern Thailand. To study factors which associate with self protecting to reduce risk of the drugs relative of hills tribe youths 


\section{Methodology}

The research design is Description Research. To select research area using Purposive Sampling. The selected area is hills tribe village Amphoe PhobPhra, Tak Province, Thailand.

\section{Population}

Population in this study are children and youths who are in education or uneducated. There are covered male and female living at hills Amphoe Phob Phra, Tak Province, age 10 to 17 years old, for 596 persons.

\section{Samples}

To random sampling samples using Cluster Random Sampling. They are youths who is 10 to 17 years old (Using Krejcie and Morgan, 1970: 607-610 for calculation). After that, we sampling family living each Tambon using Simple Random Sampling. There are sample distribution following population so, we get samples for 223 persons.

Research Tools consists of opened and closed Questionnaire which we could get personal information from sample.

In the questionnaire, there are question follows 1) Basis inquiries, 2) General inquiries, 3) Health inquiries, 4) Social inquires, 5) Cultural inquiries, 6) Drugs inquiries and 7) Mind protect from drugs inquiries.

\section{Data Analysis}

The questionnaire was recorded to computer using code guidance. Data was computed by Statistics, Mean, Standard Deviation; S.D. and predicted factors using Binary Logistic Regression and Odds ratio including 95\% Confident Interval; CL.

\section{Results and Discussion}

\section{Basis Information}

Mostly hills tribe youths sample who was in this study are students for $58.83 \%$ and $14.16 \%$ are uneducated as show in from Table 1. There are male $59.2 \%$ and female $40.8 \%$ consists of 14 years old $34.8 \%, 15$ years old $30.5 \%$ and 13 years old $20.2 \%$. Average age is 13.96 years old. Youngest and eldest are 12 and 18 years respectively.

For marital status of parents, mostly they are married and lived together for $88.4 \%$. For other who were widow, separated and single are $6.4 \%, 3.0 \%$ and $2.1 \%$ respectively.

Agricultures are main occupation of father. And who are contractors, trade, the others as employee, government official, state enterprise official and own business for $83.7 \%, 6.9 \%, 4.7 \%, 2.1 \%, 1.3 \%, 0.9 \%$ and $0.4 \%$ respectively.

For mothers, they are mostly agricultures also. The others are contractors, employee and own business as $84.5 \%$, $6.4 \%, 6.0 \%, 2.1 \%$, and $0.9 \%$ respectively.

The family which there are brother or sister for 4-6 peoples have $38.6 \%$, and 1-3 persons, 7-9 persons, only one child and others are $28.3 \%, 27.0 \%, 3.4 \%$ and $2.6 \%$ respectively.

\section{Hills tribe youth problem information}

The privacy problem was found that because of bad at learning for $21.0 \%$, poverty for $20.2 \%$, family trouble for $15.9 \%$, bad health for $15.0 \%$, fighting with others for $14.6 \%$, broken heart for $4.3 \%$, alone for $1.7 \%$ respectively. When they got in trouble, they would consult with their family for $49.4 \%$, friends for $28.3 \%$, parents for $25.8 \%$, 
mothers for $23.6 \%$, teachers for $16.7 \%$, father for $8.2 \%$, cousins for $3.9 \%$, no have to consult for $3.4 \%$ and lover for $2.6 \%$ respectively.

\section{Social Information}

Social information of hills tribe youth, tribe named Mong, was found that there are social information for rarely happened as following, parents fighting for $68.7 \%$, go shopping for $53.65 \%$, never see adult movie for $84.9 \%$, on the phone for $62.2 \%$, surf the internet for $72.5 \%$, download music/picture/game/text for $54.9 \%$, play offline/online game for $54.5 \%$, stay home with friends for $63.5 \%$, stay home alone after school for $54.5 \%$. There are only abuse matter and go night out that they never do for $85.0 \%$ and $61.8 \%$ respectively.

After researching, there are $16 \%$ persons who ever smoking, for alcohol drinking $30 \%$, for using volatile $13.6 \%$. This result was accorded to research of Jirawat Mulsart (2002), Drugs Using Behavior in High School Students: Study Case of High School in Ubon Ratchathani Province which show as student drink alcohol, beers and smoking since they have been in middle school. They start using drugs uncertainly that up to their chance or if they have friends who use drugs. The beginning of their using is friend grouping as night out, party, drinking party, class skipping or absent from class that there were using persons. After that they was invited to try or tried by themselves and use continuously as a group. The most vital which effected to drugs using is oneself. For the other factors are indirect as surrounding, school, family, friend grouping behavior and getting drugs easily. This result was also accorded to research of Sheppard G. Kellam, Margaret E. Ensminger, Marlene B. Simon (1980)The former Woodlawn. First graders, now aged 16-17, used beer or wine, hard liquor, marijuana or hashish, and cigarettes with considerable frequency. Psychedelics, amphetamines, barbiturates, tranquilizers, opiates, cocaine, inhalants, and cough syrup or codeine were used with much lower frequency. Three separate kinds of characteristics observable in first grade were associated with drug use by adolescents ten years later.

Table.1 Self-Protecting from the Drugs Data information

\begin{tabular}{|c|c|c|c|c|c|c|}
\hline \multirow[b]{2}{*}{ No. } & \multirow[b]{2}{*}{ Self-Protecting from the Drugs } & \multicolumn{5}{|c|}{ Behavior Levels } \\
\hline & & $\begin{array}{l}\text { Always } \\
\text { Persons } \\
(\%)\end{array}$ & $\begin{array}{l}\text { Often } \\
\text { Persons } \\
(\%)\end{array}$ & $\begin{array}{l}\text { Sometimes } \\
\text { Persons } \\
(\%)\end{array}$ & $\begin{array}{l}\text { Rarely } \\
\text { Persons } \\
(\%)\end{array}$ & $\begin{array}{c}\text { Never } \\
\text { Persons } \\
(\%)\end{array}$ \\
\hline 1 & $\begin{array}{l}\text { You are careful with stranger who gives drugs } \\
\text { or induce you to use drugs. }\end{array}$ & $\begin{array}{c}85 \\
(36.5)\end{array}$ & $\begin{array}{c}53 \\
(22.7)\end{array}$ & $\begin{array}{c}17 \\
(7.3)\end{array}$ & $\begin{array}{c}9 \\
(3.9)\end{array}$ & $\begin{array}{c}69 \\
(29.6)\end{array}$ \\
\hline 2 & $\begin{array}{l}\text { You can protect yourself fromany types of } \\
\text { drugs using refusal skills. }\end{array}$ & $\begin{array}{c}117 \\
(50.2)\end{array}$ & $\begin{array}{c}46 \\
(19.7)\end{array}$ & $\begin{array}{c}12 \\
(5.2)\end{array}$ & $\begin{array}{c}5 \\
(2.1)\end{array}$ & $\begin{array}{c}53 \\
(22.7)\end{array}$ \\
\hline 3 & $\begin{array}{l}\text { You can avoid behavior which there are risks to } \\
\text { use drugs as going night out or meeting for } \\
\text { unlawful purpose without caretaker. }\end{array}$ & $\begin{array}{c}115 \\
(49.4)\end{array}$ & $\begin{array}{c}41 \\
(17.6)\end{array}$ & $\begin{array}{c}8 \\
(3.4)\end{array}$ & $\begin{array}{c}9 \\
(3.9)\end{array}$ & $\begin{array}{c}60 \\
(25.8)\end{array}$ \\
\hline 4 & $\begin{array}{l}\text { You would like to be disciplined for daily life } \\
\text { that makes you away from drugs. }\end{array}$ & $\begin{array}{c}122 \\
(52.4)\end{array}$ & $\begin{array}{c}64 \\
(27.5)\end{array}$ & $\begin{array}{c}17 \\
(7.3)\end{array}$ & $\begin{array}{c}8 \\
(3.4)\end{array}$ & $\begin{array}{c}22 \\
(9.4)\end{array}$ \\
\hline 5 & $\begin{array}{l}\text { If you are stress because of learning, friends, } \\
\text { love or family, you can relax yourself without }\end{array}$ & $\begin{array}{c}74 \\
(31.8)\end{array}$ & $\begin{array}{c}51 \\
(21.9)\end{array}$ & $\begin{array}{c}30 \\
(12.9)\end{array}$ & $\begin{array}{c}24 \\
(10.3)\end{array}$ & $\begin{array}{c}54 \\
(23.2)\end{array}$ \\
\hline
\end{tabular}




\begin{tabular}{|c|c|c|c|c|c|c|}
\hline & using drugs. & & & & & \\
\hline 6 & $\begin{array}{l}\text { You can avoid drinking alcohol because it could } \\
\text { be chance to use drugs easily. }\end{array}$ & $\begin{array}{c}97 \\
(41.6)\end{array}$ & $\begin{array}{c}51 \\
(21.9)\end{array}$ & $\begin{array}{c}10 \\
(4.3)\end{array}$ & $\begin{array}{c}13 \\
(5.6)\end{array}$ & $\begin{array}{c}62 \\
(26.6)\end{array}$ \\
\hline 7 & $\begin{array}{l}\text { If you have free time after school, you prefer } \\
\text { reading a books, watching movies, playing } \\
\text { sports as your hobbies rather than having party. }\end{array}$ & $\begin{array}{c}87 \\
(37.3)\end{array}$ & $\begin{array}{c}74 \\
(31.8)\end{array}$ & $\begin{array}{c}43 \\
(18.5)\end{array}$ & $\begin{array}{c}14 \\
(6.0)\end{array}$ & $\begin{array}{l}15 \\
(6.4)\end{array}$ \\
\hline 8 & $\begin{array}{l}\text { You always refuse immediately if your friends } \\
\text { give some drugs and invite you to try it. }\end{array}$ & $\begin{array}{c}112 \\
(48.1)\end{array}$ & $\begin{array}{c}46 \\
(19.7) \\
\end{array}$ & $\begin{array}{c}13 \\
(5.6)\end{array}$ & $\begin{array}{c}10 \\
(4.3)\end{array}$ & $\begin{array}{c}52 \\
(22.3) \\
\end{array}$ \\
\hline 9 & $\begin{array}{l}\text { You have ever disappointed and stressed because } \\
\text { of friends but you can get over it without using } \\
\text { drugs. }\end{array}$ & $\begin{array}{c}87 \\
(37.3)\end{array}$ & $\begin{array}{c}65 \\
(27.9)\end{array}$ & $\begin{array}{c}23 \\
(9.9)\end{array}$ & $\begin{array}{l}15 \\
(6.4)\end{array}$ & $\begin{array}{c}43 \\
(18.5)\end{array}$ \\
\hline 10 & $\begin{array}{l}\text { You wouldn't make friends with anyone who } \\
\text { using drugs. }\end{array}$ & $\begin{array}{c}97 \\
(41.6)\end{array}$ & $\begin{array}{c}71 \\
(30.5)\end{array}$ & $\begin{array}{l}16 \\
(6.9)\end{array}$ & $\begin{array}{c}3 \\
(1.3)\end{array}$ & $\begin{array}{c}46 \\
(19.7)\end{array}$ \\
\hline 11 & $\begin{array}{l}\text { You can live without drugs even if your } \\
\text { habitation was surrounded by drugs using areas. }\end{array}$ & $\begin{array}{c}101 \\
(43.3) \\
\end{array}$ & $\begin{array}{c}69 \\
(29.6) \\
\end{array}$ & $\begin{array}{r}20 \\
(8.6) \\
\end{array}$ & $\begin{array}{c}11 \\
(4.7) \\
\end{array}$ & $\begin{array}{c}32 \\
(13.7) \\
\end{array}$ \\
\hline 12 & $\begin{array}{l}\text { You never use drug with your strong mind even } \\
\text { if your friends request or threaten you to use } \\
\text { drugs. }\end{array}$ & $\begin{array}{c}118 \\
(50.6)\end{array}$ & $\begin{array}{c}49 \\
(21.0)\end{array}$ & $\begin{array}{c}15 \\
(6.4)\end{array}$ & $\begin{array}{c}7 \\
(3.0)\end{array}$ & $\begin{array}{c}44 \\
(18.9)\end{array}$ \\
\hline 13 & $\begin{array}{l}\text { Your parents warn you about drugs relating or } \\
\text { drugs using. }\end{array}$ & $\begin{array}{c}133 \\
(57.1) \\
\end{array}$ & $\begin{array}{c}47 \\
(20.2) \\
\end{array}$ & $\begin{array}{c}20 \\
(8.6) \\
\end{array}$ & $\begin{array}{c}7 \\
(3.0) \\
\end{array}$ & $\begin{array}{c}26 \\
(11.2) \\
\end{array}$ \\
\hline 14 & $\begin{array}{l}\text { Your family will regret and be unacceptable if } \\
\text { you use drugs. }\end{array}$ & $\begin{array}{c}114 \\
(48.9) \\
\end{array}$ & $\begin{array}{c}53 \\
(22.7) \\
\end{array}$ & $\begin{array}{c}18 \\
(7.7) \\
\end{array}$ & $\begin{array}{c}6 \\
(2.6) \\
\end{array}$ & $\begin{array}{c}42 \\
(18.0) \\
\end{array}$ \\
\hline 15 & $\begin{array}{l}\text { If you have free time, you prefer going to work } \\
\text { and help your family rather than going outside. }\end{array}$ & $\begin{array}{c}109 \\
(46.8) \\
\end{array}$ & $\begin{array}{c}64 \\
(27.5) \\
\end{array}$ & $\begin{array}{c}30 \\
(12.9) \\
\end{array}$ & $\begin{array}{c}9 \\
(3.9)\end{array}$ & $\begin{array}{c}21 \\
(9.0)\end{array}$ \\
\hline 16 & $\begin{array}{l}\text { You have ever been upset because of your } \\
\text { family but you never use drugs. }\end{array}$ & $\begin{array}{c}99 \\
(42.5) \\
\end{array}$ & $\begin{array}{c}65 \\
(27.9) \\
\end{array}$ & $\begin{array}{c}33 \\
(14.2) \\
\end{array}$ & $\begin{array}{c}5 \\
(2.1) \\
\end{array}$ & $\begin{array}{c}31 \\
(13.3) \\
\end{array}$ \\
\hline 17 & You cannot use drugs because of your religion. & $\begin{array}{c}84 \\
(36.1) \\
\end{array}$ & $\begin{array}{c}73 \\
(31.3) \\
\end{array}$ & $\begin{array}{c}20 \\
(8.6) \\
\end{array}$ & $\begin{array}{c}13 \\
(5.6) \\
\end{array}$ & $\begin{array}{c}43 \\
(18.5) \\
\end{array}$ \\
\hline 18 & $\begin{array}{l}\text { You don't use drugs because of your family } \\
\text { disgrace. }\end{array}$ & $\begin{array}{c}129 \\
(55.4) \\
\end{array}$ & $\begin{array}{c}52 \\
(22.3) \\
\end{array}$ & $\begin{array}{c}16 \\
(6.9)\end{array}$ & $\begin{array}{c}7 \\
(3.0) \\
\end{array}$ & $\begin{array}{c}29 \\
(12.4) \\
\end{array}$ \\
\hline 19 & $\begin{array}{l}\text { You obey your teaches or elder about drugs } \\
\text { irrelevant. }\end{array}$ & $\begin{array}{c}134 \\
(57.5) \\
\end{array}$ & $\begin{array}{c}55 \\
(23.6) \\
\end{array}$ & $\begin{array}{c}13 \\
(5.6)\end{array}$ & $\begin{array}{c}6 \\
(2.6) \\
\end{array}$ & $\begin{array}{c}25 \\
(10.7)\end{array}$ \\
\hline 20 & $\begin{array}{l}\text { You don’t use drugs because of your school } \\
\text { disgrace. }\end{array}$ & $\begin{array}{c}98 \\
(42.1)\end{array}$ & $\begin{array}{c}79 \\
(33.9)\end{array}$ & $\begin{array}{c}18 \\
(7.7)\end{array}$ & $\begin{array}{c}8 \\
(3.4)\end{array}$ & $\begin{array}{c}30 \\
(12.9)\end{array}$ \\
\hline 21 & $\begin{array}{l}\text { You mind if you was arrested because of drugs, } \\
\text { you will lose your learning in the future. }\end{array}$ & $\begin{array}{c}107 \\
(45.9)\end{array}$ & $\begin{array}{c}59 \\
(25.3) \\
\end{array}$ & $\begin{array}{c}13 \\
(5.6) \\
\end{array}$ & $\begin{array}{c}11 \\
(4.7) \\
\end{array}$ & $\begin{array}{c}43 \\
(18.5) \\
\end{array}$ \\
\hline 22 & $\begin{array}{l}\text { You are well-known of drugs dangerous so, you } \\
\text { are not use or be relate with any drugs. }\end{array}$ & $\begin{array}{c}101 \\
(43.3)\end{array}$ & $\begin{array}{c}69 \\
(29.6)\end{array}$ & $\begin{array}{c}19 \\
(8.2)\end{array}$ & $\begin{array}{c}12 \\
(5.2)\end{array}$ & $\begin{array}{c}32 \\
(13.7)\end{array}$ \\
\hline 23 & $\begin{array}{l}\text { You found that your school haveanti-drugs } \\
\text { campaign for students. }\end{array}$ & $\begin{array}{c}110 \\
(47.2)\end{array}$ & $\begin{array}{c}67 \\
(28.8) \\
\end{array}$ & $\begin{array}{c}26 \\
(11.2) \\
\end{array}$ & $\begin{array}{c}8 \\
(3.4) \\
\end{array}$ & $\begin{array}{r}22 \\
(9.4) \\
\end{array}$ \\
\hline
\end{tabular}

Table 1 Data analysis of self-protecting behavior from drugs was showed that 134 persons or $57.5 \%$ obey teaches or elder about drugs irrelevant, 133 persons or $57.1 \%$ for parents warning about drugs relating or drugs using and there are 129 persons or $55.4 \%$ who don't use drugs because of family disgrace respectively. 
Table.2 Table 1 Data analysis of self-protecting behavior from drugs was showed that 134 persons or $57.5 \%$ obey teaches or elder about drugs irrelevant, 133 persons or $57.1 \%$ for parents warning about drugs relating or drugs using and there are 129 persons or 55.4\% who don't use drugs because of family disgrace respectively.

\begin{tabular}{|c|c|c|c|c|c|c|}
\hline \multirow{2}{*}{$\begin{array}{l}\mathrm{N}=233 \\
\text { Factors }\end{array}$} & \multicolumn{6}{|c|}{ Mind Protecting from Drugs } \\
\hline & B & S.E & Wald & df & Sig. & $\operatorname{Exp}(B)$ \\
\hline $\operatorname{sex}$ & .493 & .439 & 1.000 & 1 & .317 & 1.552 \\
\hline age & -.008 & .022 & .132 & 1 & .716 & .992 \\
\hline $\begin{array}{l}\text { being with } \\
\text { friends }\end{array}$ & .287 & .585 & .242 & 1 & .023 & 1.333 \\
\hline $\begin{array}{l}\text { Have been ser } \\
\text { alcohol in } \\
\text { traditional } \\
\text { ceremony }\end{array}$ & .750 & .613 & 1.495 & 1 & .221 & 2.117 \\
\hline Have had sex & -.082 & .414 & .039 & 1 & .842 & .921 \\
\hline deprivation & -1.427 & .641 & $4.955^{*}$ & 1 & .026 & .240 \\
\hline Go night out & .068 & .086 & .634 & 1 & .426 & 1.071 \\
\hline $\begin{array}{l}\text { Have parents } \\
\text { drinking or } \\
\text { smoking }\end{array}$ & -.152 & .058 & $6.733^{*}$ & 1 & .009 & .859 \\
\hline $\begin{array}{l}\text { Poor family } \\
\text { relationship }\end{array}$ & .000 & .000 & .337 & 1 & .562 & 1.000 \\
\hline Constant & 2.298 & 1.471 & 2.441 & 1 & .118 & 9.955 \\
\hline
\end{tabular}

Table 2 was found that value of self-protecting from drugs behavior could be predicted by equation as $59.80 \%\left(\chi^{2}=\right.$ $\left.6.455, * \operatorname{Sig}=.05, \mathrm{R}^{2}=.598\right)$. There are factors which have relative to self-protecting from drugs behavior as being with friends, deprivation and have parents drinking or smoking. It could be predicted self-protecting from drugs behavior statistically significantly 0.05 (Wald $=4.955$ และ6.733).

In this study, the children and youths who live in high area Amphoe PobPhra have parents drinking or smoking. They have ever asked for buy alcohol or cigarette to elder who have related with their mind protecting. That was accorded to youth research of Niramon Preancharoon (2012), Factors of Drugs Using in High School Students which study the alcohol drinking in family behavior. There are more than half of all fathers, half of cousins and nearly half of living members of students drinking alcohol.
For smoking, more than half of all fathers, cousins, parents and living members are smoking but almost all of mothers are not smoking. For gamble, there are more than $3 / 4$ of students intimate who are not gamble.

In addition parents and teachers play an important role in integrating youth into community, and attachment to school is a significant protective factor against narcotic use. Being with friends, deprivation and have parents drinking or smoking are linked 
to narcotic use, crime and other risky behaviour. It is important to intervene early to break this cycle of disengagement. This result was also accorded to research of Botvin, G. J., Griffin, K. W., Nichols, T. R. (2006), evidence-based drug education programmes which have been shown in the US and Europe to reduce alcohol use among young people include 'Life Skills Training' and 'Unplugged'. An enhanced version of the former has also been found to reduce violence and aggression among students.

\section{Suggestions}

1) School and community should have situation survey for drugs using of youths continuously. Then, get information to the community stage to watch out and determine for making community plans.

2) There should be description for persons who are concern with anti-drug activity for youth living in community.

3) Tambon Health Promoting Hospital should be host for program management in next time.

\section{References}

Botvin, G.J., Griffin, K.W., Nichols, T.R. 2006. Preventing youth violence and delinquency through a universal schoolbased prevention approach. Prevention Sci., 7: 403-408.

Food and drug administration, Thailand. Harm of drug (Cited 21 June 2016)
International Cooperation suppression Bureau Drug. The drug situation in the world. (Cited 21 June 2016) Available from http://nctc.oncb.go.th/ewt_w3c/ewt_new s.php?nid $=334 \&$ filename $=$ (in Thai)

Jill Levenson, Melissa Grady. 2016. Childhood Adversity, Substance Abuse, and Violence: Implications for TraumaInformed Social Work Practice Journal of Social Work Practice in the Addictions

Jirawat Mulsart. 2002. Drugs Using Behavior in High School Students: Study Case of High School in Ubon Ratchathani Province, J. Psychiatric Assoc.Thailand, Volume 47, Number of issue 2 Apr-Jun 2002 p. 121.

Niramon Preancharoon, Factors of Drugs Using in High School Students. King Mongkut's University of Technology North Bangkok 2012. http://library.uru.ac.th/dbresearch/image s/S114b.htm

Office of Narcotic control board. The concept of development to prevent and resolve drug (Cited 21 June 2016) Available from

http://www.oncb.go.th/PortalWeb/appm anager/Portal/Internet(in Thai)

Pranee Sutthisukhon and others. 2008. Family relationship With health care. Bangkok: P.A. living 8

Sheppard, G., Kellam, Margaret, E.. Ensminger, Marlene, B., Simon. 1980. Drug and Alcohol Dependence Volume 5, Issue 4, April 1980, Pages 273-304.

Thana Yottrakul. 2008. Border Management, J. Security Study, No 53.

\section{How to cite this article:}

Narongsak Noosorn and Chakgarpan Phetphoom. 2016. Self-Protecting from Drugs for Hills Tribe Youth Living in Border Area of Northern Thailand. Int.J.Curr.Microbiol.App.Sci. 5(7): 794-800. doi: http://dx.doi.org/10.20546/ijcmas.2016.507.091 